Adrian W. Gelb MBCHB FRCPC, Phillip Floyd BSC HONs, Peter Lok RRT, Sydney J. Peerless MD FRCPSC, Michael Farrell MRCP(I) MRCPATH

\title{
A prophylactic bolus of thiopentone does not protect against prolonged focal cerebral ischaemia
}

Barbiturate coma is still recommended for brain protection during periods of temporary focal ischaemia such as during carotid endarterectomy. We tested the hypothesis that a single dose of barbiturate given before a period of protracted severe focal ischaemia would protect against focal cerebral infarction.

Sixteen cats had the proximal left middle cerebral artery (MCA) occluded. Eight cats received halothane alone titrated to keep their pulse and blood pressure within the normal range. Eight cats received, in addition to halothane, a bolus of thiopentone sufficient to produce an isoelectric EEG immediately prior to MCA occlusion. Six hours after the occlusions the animals were sacrificed and the brains scored histologically to assess both size and severity of ischaemia.

There was no statistically significant difference in the size or severity of the infarcts between the groups.

We conclude from this study that the extent of the histological injury was not reduced by a single prophylactic bolus of thiopentone given before prolonged focal cerebral ischaemia.

\section{Key words}

ANAESTHETICS INTRAVENOUS: thiopentone; BRAIN: infarction.

From The Departments of Anaesthesia and Clinical Neurological Sciences, University Hospital, University of Western Ontario, London, Ontario, Canada.

Address correspondence to: Dr. A.W. Gelb, Department of Anaesthesia, University Hospital, P.O. Box 5339, Station "A," London, Ontario, Canada N6A 5A5. Supported by the Ontario Heart Foundation Grant \# 3-20.
Prophylactic barbiturate coma is recommended for brain protection during periods of temporary focal ischaemia such as carotid endarterectomy, aneurysm clipping, and extracranial to intracranial bypass procedures. ${ }^{1-6}$ The common clinical practice is to give a bolus of barbiturate at the time that the patient is at risk. ${ }^{2,4,5,7}$ Relatively small single doses are often used because larger doses are associated with hypotension, and because of concem that druginduced coma would delay the diagnosis of neurologic dysfunction in the immediate postoperative period. In this study, we tested the hypothesis that a single dose of barbiturate given before a period of protracted severe focal ischaemia would protect against focal cerebral infarction. We speculated that sufficient drug would be trapped in the ischaemic zone to be protective.

\section{Methods}

Sixteen cats, each weighing between 2 and $4 \mathrm{~kg}$, were studied. Anaesthesia was induced with intraperitoneal ketamine hydrochloride $\left(10 \mathrm{mg} \cdot \mathrm{kg}^{-1}\right)$ and atropine $\left(0.05 \mathrm{mg} \cdot \mathrm{kg}^{-1}\right)$. The ketamine was given at least three hours before vessel occlusion and no additional doses were given. All animals were intubated and mechanically ventilated with 60 per cent oxygen (air/oxygen). Pancuronium bromide was used for muscle relaxation. A catheter was inserted into a femoral artery for continuous blood pressure measurement and a venous cannula was placed in the cephalic vein for fluid (lactated Ringer's solution $2 \mathrm{ml} \cdot \mathrm{kg}^{-1} \cdot \mathrm{hr}^{-1}$ ) and drug administration.

The animals were kept normothermic by means of a heating pad and incandescent lamps. Blood pressure and heart rate (EKG) were continuously displayed and end-tidal $\mathrm{CO}_{2}$ was monitored with a 
Hewlett-Packard infra-red end-tidal capnometer. Arterial blood gases were sampled hourly. The $\mathrm{PaO}_{2}$ was kept above $100 \mathrm{mmHg}$ and $\mathrm{PaCO}_{2}$ between $30-35 \mathrm{mmHg}$. The $\mathrm{pH}$, adjusted with intravenous bicarbonate when needed, was maintained within the normal range.

The head of each cat was shaved and placed in a head holder which allowed unobstructed access to the left orbit. A pair of frontoparietal EEG electrodes were attached approximately $1 \mathrm{~cm}$ lateral to the midline over each hemisphere. The reference electrode was placed over the frontal air sinus. This montage spanned the region of ischaemia. Tracings were recorded on a Grass EEG recorder. The middle cerebral artery (MCA) was reached by evacuating the orbital contents and unroofing the optic foramen. Using microsurgical techniques, the dura and arachnoid were incised and the proximal middle cerebral artery carefully dissected free from adjacent structures. At the appropriate time, the vessel was cauterized and bisected.

The animals were divided into two study groups. Group 1: eight cats received halothane (0.5-1.5 per cent) alone, titrated to keep their pulse and blood pressure within the normal range. These animals served as the control group. Group 2: eight cats received halothane $(0.5-1.5$ per cent) until ten minutes before vessel occlusion when it was stopped. Immediately prior to MCA occlusion, they were given a bolus of thiopentone sufficient to produce EEG burst suppression. No further thiopentone was given. After the occlusion, tachycardia or increases in blood pressure greater than 20 per cent of base-line were treated as they would be in the operating room, by increasing the concentration of halothane. Hypotension, which occurred after the thiopentone boluses, was treated first with a bolus of intravenous fluid (lactated Ringer's solution $5-10 \mathrm{ml} \cdot \mathrm{kg}^{-1}$ ) and then with intravenous phenylephrine.

The cats were maintained ventilated and anaesthetized for six hours after the occlusion and then sacrificed by barbiturate overdose. The ascending aorta was cannulated and after cross-clamping the descending aorta and incising the superior vena cava, $250 \mathrm{ml}$ of normal saline and $500 \mathrm{ml}$ of ten per cent phosphate buffered formalin was infused into the cerebral circulation. The brain was then carefully removed and fixed in ten per cent formalin for at least two weeks. The macroscopic appearance

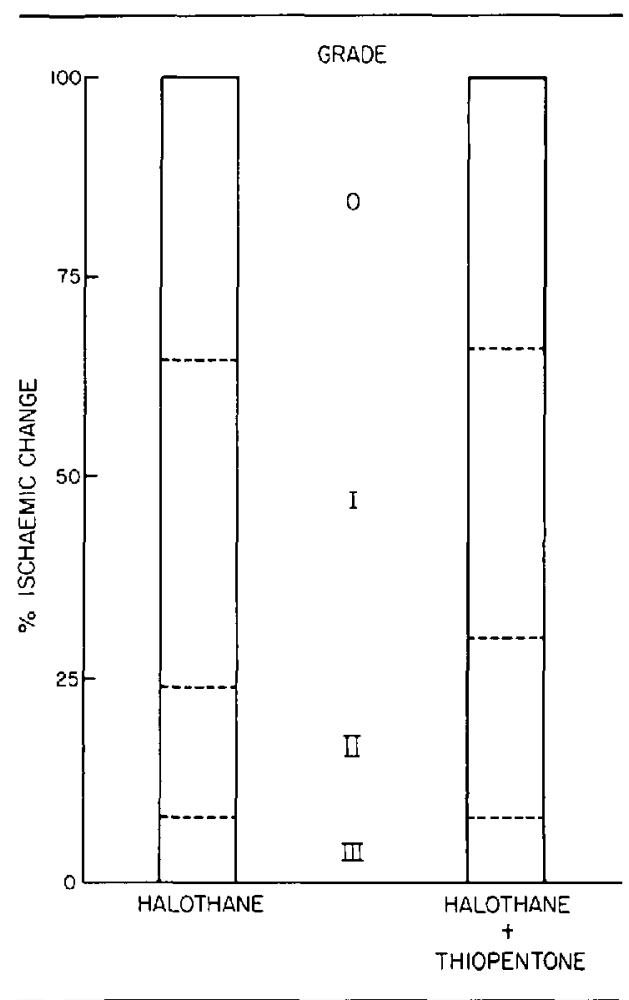

FIGURE Mean ischaemic neuronal alterations expressed as a percentage of the total hemispheric gray matter. $0=$ notmal, I = mild histological changes, II = moderate histological changes, III = severe histological changes.

of the brain was photographed and complete sectioning of the proximal left MCA was confirmed by inspection. A coronal section five micrometers thick was then taken at the level of the optic chiasm, and stained with hematoxylin and eosin. A section at this level includes the ectosylvian, suprasylvian, marginal, and anterior sylvian gyri. Experience in our laboratory as well as in the literature indicates that this is the region most consistently and severely affected by MCA occlusion. ${ }^{8,9}$ The mounted sections were examined by a neuropathologist (MF) blinded to the treatment groups and the extent of the gray matter injury was recorded on a $10 \times 8$ photograph of the section. A standardized, previously described histological scoring system was used. ${ }^{9}$ Briefly, the brain was graded as normal, or as showing evidence of mild (grade 1), moderate (grade 2), or severe (grade 3) ischaemic injury. The 
TABLE I Results-Blood pressure, temperature, blood gases

\begin{tabular}{|c|c|c|c|c|c|c|c|c|c|c|}
\hline & \multicolumn{5}{|c|}{ Halothane (group I) } & \multicolumn{5}{|c|}{ Halothane + thiopentone (group 2) } \\
\hline & PreOccl & occl & 1 hour & 3 hour & 6 hour & PreOccl & Occl & I hour & 3 hour & 6 hour \\
\hline Mean & 83.0 & 88.2 & 92.8 & 93.7 & 94.2 & 89.4 & 90.2 & 95.6 & 94.5 & 97.0 \\
\hline $\begin{array}{l}\mathrm{BP} \\
(\mathrm{mmH})\end{array}$ & \pm 13.3 & \pm 13.8 & \pm 13.8 & \pm 7.1 & \pm 10.7 & \pm 13.5 & \pm 25.5 & \pm 14.3 & \pm 9.8 & \pm 8.3 \\
\hline $\begin{array}{l}\text { Temp } \\
\left({ }^{\circ} \mathrm{C}\right)\end{array}$ & $\begin{array}{r}37.7 \\
\pm 1.3\end{array}$ & $\begin{array}{r}38.0 \\
\pm 1.2\end{array}$ & $\begin{array}{c}38.2 \\
\pm 0.75\end{array}$ & $\begin{array}{r}38.4 \\
\pm 0.6\end{array}$ & $\begin{array}{c}38.4 \\
\pm 0.82\end{array}$ & $\begin{array}{c}37.9 \\
\pm 0.86\end{array}$ & $\begin{array}{r}37.9 \\
\pm 0.9\end{array}$ & $\begin{array}{r}37.8 \\
\pm 0.9\end{array}$ & $\begin{array}{c}37.9 \\
\pm 0.82\end{array}$ & $\begin{array}{r}38.1 \\
\pm 1.0\end{array}$ \\
\hline $\mathrm{pH}$ & $\begin{array}{r}7.34 \\
\pm 0.1\end{array}$ & $\begin{array}{r}7.38 \\
\pm 0.06\end{array}$ & $\begin{array}{r}7.34 \\
\pm 0.07\end{array}$ & $\begin{array}{r}7.37 \\
\pm 0.06\end{array}$ & $\begin{array}{r}7.34 \\
\pm 0.06\end{array}$ & $\begin{array}{r}7.40 \\
\pm 0.04\end{array}$ & $\begin{array}{r}7.38 \\
\pm 0.04\end{array}$ & $\begin{array}{r}7.33 \\
\pm 0.06\end{array}$ & $\begin{array}{r}7.37 \\
\pm 0.02\end{array}$ & $\begin{array}{r}7.37 \\
\pm 0.04\end{array}$ \\
\hline $\begin{array}{l}\mathrm{PaCO}_{2} \\
(\mathrm{mmHg})\end{array}$ & $\begin{array}{r}32.3 \\
\pm 3.6\end{array}$ & $\begin{array}{r}33.6 \\
\pm 1.5\end{array}$ & $\begin{array}{r}35.6 \\
\pm 4.9\end{array}$ & $\begin{array}{r}37.4 \\
\pm 5.0\end{array}$ & $\begin{array}{r}34.3 \\
\pm 3.4\end{array}$ & $\begin{array}{r}32.7 \\
\pm 3.0\end{array}$ & $\begin{array}{r}33.5 \\
\pm 1.6\end{array}$ & $\begin{array}{r}33.9 \\
\pm 4.2\end{array}$ & $\begin{array}{r}33.6 \\
\pm 3.3\end{array}$ & $\begin{array}{r}34.3 \\
\pm 3.0\end{array}$ \\
\hline
\end{tabular}

Values are Mean = S.D. PreOccl = mean for the entire period before occlusion. Occl = mean for the time of occlusion and fifteen minutes immediately after. One hour, three hours, six hours = mean for the first, third, and sixth hour after occlusion.

TABLE II Area of ischaemic neuronal damage

\begin{tabular}{lrr}
\hline Grade & Halothane & $\begin{array}{c}\text { Halothane }+ \\
\text { thiopentone }\end{array}$ \\
\hline Mild (I) & $37.6 \pm 5.7$ & $35.5 \pm 8.9$ \\
Moderate (II) & $15.7 \pm 4.9$ & $21.6 \pm 5.3$ \\
Severe (III) & $7.8 \pm 2.7$ & $8.2 \pm 5.5$ \\
\hline
\end{tabular}

Area is expressed as a $\%$ of cortical gray matter. Values are Mean \pm SEM.

areas of each grade were summated and expressed as a percentage of the total hemispheric gray matter. Statistical anaylsis was by analysis of variance.

\section{Results}

All the animals survived the study period. Hypotension requiring small boluses of phenylephrine occurred in all the group 2 animals after the boluses of thiopentone were given. Phenylephrine was not required by any animal in group 1 . Thiopentone $40.6 \pm 11.5 \mathrm{mg} \cdot \mathrm{kg}^{-1}$ (mean $\pm \mathrm{SD}$ ) was given to the group 2 animals to achieve an isoelectric EEG. In both groups, after vessel occlusion, $0.25-1.5$ per cent halothane was used to control increases in blood pressure greater than 20 per cent above the pre-occlusion levels. This was required within one hour of the occlusion in all but one animal. There was no difference in the duration or depth of halothane anaesthesia used in the two groups. EEG activity had returned by one hour post-occlusion in all the group 2 animals. Animals in both groups had left hemispheric EEG slowing and/or a reduction in amplitude indicative of cerebral ischaemia.

Blood pressure, heart rate, temperature and arterial blood gases were compared for each one hour epoch and no statistically significant differences found (Table I).

The results of the histological analysis are shown in Table II and the Figure. There was no statistically significant difference in the size or severity of the infarcts between the two groups.

\section{Discussion}

Barbiturates have been used to protect the brain during periods of risk for temporary focal ischaemia. ${ }^{1-6}$ The aim of this study was to see if this would impute any benefit if a prolonged period of focal ischaemia were to occur during the period of risk. Our results indicate that no detectable benefit accrues.

The transorbital occlusion of the MCA in the cat is a standard model of focal ischaemia. ${ }^{9-12}$ The advantage of this feline model is that an infarct is reliably produced with minimal CSF loss and brain manipulation. As the cerebral blood flow threshold for electrical failure and for failure of ion homeostasis is similar in cats and primates, it is possible to extrapolate from one species to another. ${ }^{13,14}$ Disadvantages, shared by most animal models, are the absence of cerebrovascular atherosclerosis which would be found in most patients undergoing neurovascular surgery, and a richer leptomeningeal collateral than is found in primates. 
The latter probably accounts for the variation in the size of infarcts resulting from proximal cerebral artery occlusion. It has been postulated that after focal arterial occlusion, the zone of reversible ischaemia would be larger in the cat model than the primate because of the better collateral circulation. ${ }^{15}$ A treatment that prevents infarction should show a large reduction in infarct size in a model with the largest zone of still viable tissue at risk. This model is therefore an appropriate one for these experiments.

We chose histologically evident ischaemic damage as the end point because that represents the severest effect of ischaemia. Neural tissue passes through three phases during protracted ischaemia. ${ }^{14}$ When flow drops below a critical threshold, functional neurological impaiment occurs with EEG failure. A further fall in oxygen delivery results in metabolic derangements such as leakage of potassium into the extracellular fluid and depletion of ATP and phosphocreatine. Maintenance of this level of flow for a protracted period or a further reduction in flow ultimately results in structural cellular damage. ${ }^{12,14}$ We cannot exclude the possibility that had we used metabolic derangement as our end point or a shorter duration of ischaemia, our conclusion may have been different. Indeed grades 1 and 2 probably represent potentially viable cells so that the greater sensitivity of metabolic measurements may have detected subtle differences which were not detectable by light microscopy. However, histological assessment correlates well with clinical (functional) scoring after cerebral ischaemia and as such has clinical relevance. ${ }^{16,17}$

Over the past 20 years, there has been growing interest in the use of anaesthetic agents to protect the brain from the ravages of ischaemia. Laboratory studies showed that the barbiturates, especially thiopentone and pentobarbitone, were the most effective. Subsequent clinical evaluations in man and sub-human primates have not confirmed these benefits in global ischaemia. ${ }^{6,17}$ Barbiturates, however, are still recommended for brain protection during periods of temporary focal ischaemia such as carotid endarterectomy, extracranialintracranial anastomosis and temporary occlusion of major intracranial arteries during aneurysmal obliteration. ${ }^{1-5}$ In these circumstances it is hoped that sufficient drug is trapped in the ischaemic area to protect it until flow is re-established. Our study suggests that if flow is not rapidly re-established, no protection is afforded by a single bolus of barbiturate.

Reasons why thiopentone was not beneficial in this study were not directly addressed. Phenylephrine, which was required in all of the animals given thiopentone, does not normally cross the bloodbrain barrier or reduce cerebral blood flow although vasoconstriction was recently documented in dogs. ${ }^{18,19}$ With the ischaemic disruption of the blood-brain barrier, phenylephrine may have adversely altered cellular metabolism or blood flow and thus negated any beneficial effects of the thiopentone. This would be a potential problem with any of the clinically used vasopressors. Halothane, even in the relatively low concentrations we used, has recently been shown to prevent the re-establishment of a normal $\mathrm{pH}$ in the brain after a period of temporary focal ischaemia. ${ }^{20}$ The re-introduction of halothane in group 2 after the MCA occlusion, may therefore have diminished or reversed the beneficial effect of thiopentone. Increases in systemic blood pressure are a common consequence of cerebral ischaemia. Rather than using a non-anaesthetic vasodilator such as hydralazine or sodium nitroprusside to reduce excessive hypertension, we chose to treat the blood pressure as it would be in the operating room, by increasing the depth of anaesthesia. No animal required more than 1.5 per cent halothane which is well within the clinically acceptable dose range.

An infarct evolves over many hours. ${ }^{14}$ For thiopentone to influence infarct size, it probably must be present in the ischaemic area for the major part of this process. Because collateral blood flow allows some flow through the ischaemic area, the bulk of the drug initially trapped may be washed out. Continuation of the drug infusion may therefore be more beneficial.

We conclude from this study that the extent of the histological injury was not reduced by a single prophylactic bolus of thiopentone given before prolonged focal cerebral ischaemia. 


\section{References}

1 Gross CE, Adams HP Jr, Sokoll MD, Yamada $M D$. Use of anticoagulants, electroencephalographic monitoring, and barbiturate cerebral protection in carotid endarterectomy. Neurosurg 1981; 9: 1-5.

2 Lawner PM, Simeone FA. Treatment of intraoperative middle cerebral artery occlusion with pentobarbital and extracranial-intracranial bypass. J Neurosurg 1975; 5I: 710-2.

3 Michenfelder $J D$. Physiology and pharmacology of brain protection. American Society of Anesthesiologists Annual Refresher Course Lectures 1982: 242.

4 Spetzler RF, Selman WR, Roski RA, Banstelle C Cerebral revascularization during barbiturate coma in primates and humans. Surg Neurol 1982; 17: $111-5$.

5 Ditmore $Q M$, Samson DS, Beyer $C W$. Traumatic middle cerebral artery aneurysm: case report. Neurosurg 1980; 6: 293-6.

6 Piatt JH Jr, Schiff SJ. High dose barbiturate therapy in neurosurgery and intensive care. Neurosurg 1984; 15: 427-44.

7 Moffat JA, McDougall MJ, Brunet D et al. Thiopental bolus during caratid endarterectomy - rational drug therapy? Can Anaesth Soc J 1983; 30: 615-22.

8 Meyer KL, Dempsey RJ, Roy MW, Donaldson $D L$. Somatosensory evoked potentials as a measure of experimental cerebral ischemia. J Neurosurg 1985; 62: 269-75.

9 Peerless SJ, Ishikawa R, Hunter IG, Peerless MJ. Protective effect of fluosol-DA in acute cerebral ischemia. Stroke 1981; 12: 558-63.

10 Hayakawa $T$, Waltz $A G$. Immediate effects of cerebral ischemia: evolution and resolution of neurological deficits after experimental occlusion of one middle cerebral artery in conscious cats. Stroke 1975; 6: 321-7.

11 Waltz $A G$. Clinical relevance of models of cerebral ischemia. Stroke 1979; 10: 211-3.

12 Heiss WD, Rosner G. Functional recovery of cortical neurons as related to degree and duration of ischemia. Ann Neurol 1983; 14: 294-301.

13 Hossmann KA, Schuier FJ. Experimental brain infarcts in cats. I. Pathophysiological observations. Stroke 1980; 11: 583-92.

14 Astrup J. Energy-requiring cell functions in the ischemic brain. J Neurosurg 1982; 56: 482-97.
15 Hubbard JL, Sundt TM Jr. Failure of naloxone to affect focal incomplete cerebral ischemia and collateral blood flow in cats. J Neurosurg 1983; 59: 237-44.

16 Smith AL, Hoff JT, Nielsen SL, Larson CP. Barbiturate protection in acute focal cerebral ischemia. Stroke 1974; 5: 1-7.

17 Gisvold SE, Safar P, Hendrickx HHL et al. Thiopental treatment after global brain ischemia in pigtailed monkeys. Anesthesiology 1984; 60: 8896.

18 Geevarghese KP. Basic considerations. In: Anesthesia for Neurological Surgery. Ed: KP Geevarghese, International Anesthesiology Clinics 1977; 15: 1-56.

19 Newberg LA, Milde JH, Michenfelder JD. The cerebral metabolic effects of isoflurane at and above concentrations that suppress cortical electrical activity. Anesthesiology 1983; 59: 23-8.

20 Anderson $R E$, Sundt $T M J r$. Brain $\mathrm{pH}$ in focal cerebral ischemia and the protective effects of barbiturate anesthesia. J Cereb Blood Flow Metab 1983; $3: 493-7$.

Résumé

Le coma barbiturique est encore recommandé pour la protection cérébrale lors des épisodes d'ischémies focales temporaires comme dans l' endotérectomie carotidienne. On a étudié l'hypothèse qu'une simple dose de barbiturique donnée avant l' ischémie focale sévère peut protéger contre l' infarcissement cérébral focal.

Seize chats ont eu leur artère cérébrale moyenne gauche occluse proximalement. Huit chats ont reçu de l'halothane seule titrée afin de garder leur tension artérielle et leur pouls à la limite de la normale. Huit chats ont reçu en plus de l'halothane un bolus de thiopentone suffisant afin de produire un électroencéphalogramme lent immédiatement avant l'occlusion de la MCA. Six heures après l'occlusion les animaux ont été sacrifiés et les cerveaux étudiés histologiquement afin d'évaluer à l'étendue que la sévérité de l'ischémie.

Il n'y avait aucune différence statistiquement significative tant dans l'étendue que dans la sévérité de l'infarctus entre les deux groupes.

On conclut de cette étude que l'étendue des lésions histologiques n'était pas réduit par une simple dose prophylactique de thiopentone donnée avant l'ischémie cérébrale focale prolongée. 